\title{
Znaczenie krytycznej gerontologii edukacyjnej dla badań i praktyki
}

\author{
The meaning of critical educational gerontology for research \\ and practice
}

Streszczenie. Problem starości jest zagadnieniem atrakcyjnym i interesującym w kontekście starzejącego się społeczeństwa. Coraz więcej pojawia się badań na temat działań seniorów, ich uczestniczenia w różnych projektach, zajęciach, warsztatach na Uniwersytetach Trzeciego Wieku czy w klubach seniorów. Jednakże edukacyjny aspekt starości i starzenia się jest niewystarczająco rozpoznany naukowo. Osoby starzejące się i stare nie są w dalszym ciągu postrzegane jako potencjał edukacyjny. Artykuł porusza aspekt niejednoznacznej granicy starości oraz korzyści uczenia się w późnej dorosłości. Meritum artykułu stanowią rozważania na temat zagadnienia geragogiki krytycznej oraz krytycznej gerontologii edukacyjnej w odniesieniu do działań edukacyjnych proponowanych na wrocławskich Uniwersytetach Trzeciego Wieku.

Słowa kluczowe: uczenie się, krytyczna gerontologia edukacyjna, krytyczna geragogika, UTW, senior, uczenie się przez całe życie, granice starości

Summary. The problem of old age is an attractive and interesting issue in context of ageing society. There are quite a lot of research done on the field of activity of seniors, theirs participation in different projects and workshops at University of the Third Age or seniors' clubs. However educational aspect of ageing and old age is not enough recognized on the scientific field. The ageing and old people are not noticeable as the educational potential still. The article reflects on the aspects of moving borders of old age and profits from learning in the old. The core of the article is the issue of critical educational gerontology and critical geragogy with reference to educational activities offered at the Universities of the Third Age in Wroclaw.

Keywords: learning, critical educational gerontology, U3A, senior, lifelong learning, critical geragogy, borders of old age 


\section{4 | Małgorzata Malec Rawiński}

Problematyka starości, starzenia się czy starzejącego się społeczeństwa (polskiego, europejskiego, światowego) pojawia się coraz częściej zarówno w debacie publicznej jak i naukowej. Ageizm dołącza do listy pojęć obowiązkowych obok seksizmu, rasizmu czy mobbingu. Jednakże analizując liczne publikacje z obszaru gerontologii (Szatur-Jaworska B., Błędowski P., Dzięgielewska M. 2006; Czerniawska 2006; Leszczyńska-Rejchert 2005; Skibińska 2006; Zych 1999; Halicki 2010; Wawrzyniak 2009; Szarota 2010; Błachnio 2012; Hill 2010; Zboina 2008; Gołdys, Krzyżanowska, Stec, Ostrowski 2012) zauważam niedosyt badawczy w szeroko rozumianym edukacyjnym obszarze gerontologicznym. Istnieje wiele teorii dotyczących starzenia się, które koncentrują się głównie na biologicznych aspektach funkcjonowania organizmu ludzkiego lub uwarunkowaniach społecznych i psychicznych (szczegółowo opisywane w polskiej literaturze gerontologicznej zob. Zych, Halicki) natomiast brak jest teorii uczenia się osób starzejących się i starych. Odnoszę wrażenie, iż pomimo eksplozji Uniwersytetów Trzeciego Wieku, edukacyjny aspekt starości i starzenia się jest niewystarczająco rozpoznany naukowo. Termin geragogika krytyczna, gerontologia edukacyjna czy też krytyczna gerontologia edukacyjna są w niewielkim stopniu rozpoznane na polskim gruncie naukowym. W związku z powyższym, meritum niniejszego tekstu będą stanowić rozważania na temat zagadnienia geragogiki krytycznej oraz krytycznej gerontologii edukacyjnej w odniesieniu do działań edukacyjnych proponowanych na wrocławskich Uniwersytetach Trzeciego Wieku.

W listopadzie 2008 roku Gazeta Wyborcza opublikowała cykl artykułów nt. „Polska to nie jest kraj dla starych ludzi”. Byłam wówczas adeptką gerontologii, geragogiki i z dużym zainteresowaniem śledziłam każde kolejne wydanie cyklu. Ukazujące się artykuły budziły wiele polemik. Inspirując się opublikowanymi artykułami zorganizowaliśmy ze studentami III roku pedagogiki, specjalność Edukacja Dorosłych i Marketing Społeczny, Uniwersytetu Wrocławskiego (grudzień 2008), panel dyskusyjny na Uniwersytecie Trzeciego Wieku w Uniwersytecie Wrocławskim (UTW w UWr.). Panel przewrotnie zatytułowaliśmy „Czy Polska to jest kraj dla starych ludzi?”. W spotkaniu uczestniczyli zarówno studenci pedagogiki (w wieku 21-27 lat) jak i słuchacze UTW (po 60 r.ż). Pamiętam, iż podczas bardzo interesującego poznawczo spotkania, najwięcej kontrowersji wzbudził wówczas artykuł, który przedstawiał wywiad Doroty Wodeckiej z prof. Wiesławem Łukaszewskim pt. „Kiedy jeżdżę na rolkach smarkacze krzyczą: dziadek do piachu!”. Szczególnie dyskusyjny okazał się fragment tego wywiadu, który nawiązywał do działalności UTW: 
„(...) uniwersytety trzeciego wieku to żenada. (...) Te tzw. uniwersytety to grupy wsparcia, gdzie nieszczęśni starcy organizują sobie życie po to, żeby zająć swój czas, i po to, by tworzyć bazy danych o różnych okazyjnych darmowych wyżerkach. Nie nazywajmy tego uniwersytetami, bo to mistyfikacja. Jaki to uniwersytet? Jaka to nauka? To nieapetyczna gra pozorów. Jeśli chcemy naprawdę dać szansę kształcenia starym ludziom, niech każde miasto zafunduje kilkorgu z nich prawdziwe studia. Niech da im szansę doświadczenia sprawności intelektualnej, co jest niesamowitym przeżyciem. Taka bywa rzeczywistość szwedzka czy amerykańska. Tam w salach uniwersyteckich siedzą w jednej ławie 70-latki i 18-latki. To są koledzy ze studiów. A u nas miarą sukcesu starych »studentów « jest lepienie garnków. Bo coś trzeba robić, trzeba starych zająć, żeby nie marudzili i by niczego od nikogo nie chcieli. A jak zaczynają za dużo myśleć, to "zadamy« im jeszcze jedną makatkę. Albo pozwolimy zrobić włóczkowy beret. Dla wnuka oczywiście, a nie, broń Boże, na wystawę abakanów.

DW: Ale oni to lubią.

- Kto to udowodnił? Przede wszystkim nie mają alternatywy. Ludzie starzy mają bardzo mało przyjemności.(...)." (Wodecka, 2008)

Gdy z perspektywy czasu, doświadczeń i wiedzy, powracam do analizy tych artykułów, a szczególnie przytoczonego powyżej fragmentu, krytyczniej przyglądam się działalności edukacyjnej UTW. Bez wątpienia idea UTW to wartościowa propozycja aktywizowania seniorów, miejsce spotkań, wymiany doświadczeń oraz pozaformalnej i nieformalnej edukacji. Zastanawiam się jednak czy to społeczne i polityczne zezwolenie na powstawanie tak wielu UTW (obecnie ponad czterysta) nie tworzy swoistego getta dla ludzi starzejących się i starych, prowadząc raczej do ekskluzji niż inkluzji społecznej tej grupy wiekowej?

Podążając za rozważaniami Maxa Webera na temat „odczarowywania” świata, uważam, iż można zacząć odważniej mówić o „odczarowywaniu" starości oraz prowadzeniu badań w obszarze problematyki uczenia się osób starzejących się i starych, których wyniki, jak postuluje Marcin $\mathrm{Mu}$ szyński (2011), będą prezentować poziom teoretycznych eksplikacji. Moim zdaniem, pomocne do realizacji takich projektów (badań) mogą być założenia krytycznej gerontologii edukacyjnej, którą szerzej zaprezentuję w dalszej części artykułu. 


\section{6 | Małgorzata Malec Rawiński}

\section{Ruchome granice starości a uczenie się}

Problem starości jest zagadnieniem atrakcyjnym i interesującym badawczo w dobie społeczeństwa starzejącego się. Wiele tekstów dotyczących problematyki starości pokazuje statystyki przekonując czytelnika, iż żyjemy (i według prognoz będziemy żyć) dłużej, a osób po 60 r.ż. jest (i będzie) coraz więcej (szacuje się, iż do 2050 liczba osób w wieku 60 i więcej wzrośnie z 605 milionów do 2 bilionów jak podaje WHO). Jednakże nie ma wyraźnej granicy wkraczania w okres starości. W opinii wielu autorów (Bromley 1969; Susłowska 1989; Wiśniewska-Roszkowska 1989) wiekiem granicznym dla starości jest 70 r.ż.. Według klasyfikacji Światowej Organizacji Zdrowia (http://www.who.int/topics/ageing/en/) starość rozpoczyna się w 60 r.ż.. Natomiast w raporcie Unii Europejskiej, w badaniach przeprowadzonych przez NIACE, przyjęte jest iż seniorem/osobą starszą (older) jest osoba 50+ (McNair, 2012). Przypuszczam, iż wytyczne wieku senioralnego zaakceptowane przez EU, z jednej strony mogą być zaskoczeniem, z drugiej stają się nowym wyzwaniem dla edukacji dorosłych. Jak pokazują badania NIACE (McNair, 2012) wiele osób po 50 r.ż. (w Anglii) jest zaangażowanych zawodowo, niemniej jednak obserwuje się, iż znacząca grupa osób opuszcza pracę w tym wieku. Powodów jest wiele: pogarszający się stan zdrowia, opieka nad bliskimi, zwolnienie $\mathrm{z}$ pracy i trudność znalezienia nowej z powodu dyskryminacji na wiek; brak nieaktualnych, nieadekwatnych kwalifikacji do zapotrzebowania na rynku pracy, lub wybór niskiej, skromnej emerytury w zamian za nielubianą pracę (McNair, 2012). Brak aktywności zawodowej często wywołuje poczucie wycofania społecznego, bycie niepotrzebnym a przez to starym.

Bez wątpienia wraz z wiekiem odczuwamy spadek sił, sprawności i umiejętności. Proces starzenia się jest progresywny, nieodwracalny ale może być spowolniony. Jest całościowym i stopniowym ograniczeniem sprawności funkcjonalnej procesów biologicznych i psychicznych (Szamus-Jackowska, 2011). Wraz z procesem starzenia się zachodzą zmiany w wyglądzie (zmienia się nasze ciało). Jednakże pomimo tego, iż starość jest kolektywna, to proces starzenia się jest zindywidualizowany. Każdy doświadcza go indywidualnie. Starość jest stanem umysłu uwarunkowanym doświadczeniami, stylem życia, kulturą, warunkami socjalnymi, a także genetyką. Być może dlatego, jednoznaczne ustalenie granicy starości jest tak problematyczne zarówno w obszarze nauki jak i w codziennym rozumieniu.

Edukacyjny aspekt starości, uczenia się w starości jest traktowany z mniejszą atencją, choć idea całożyciowego uczenia się (LLL) obejmuje tak- 
że osoby w późnej dorosłości. Kontynuowanie uczenia się w wieku średnim oraz w późnej dorosłości jak pokazują badania NIACE (McNair, 2012) oraz badania Purdie, Boulton-Lewis (2003 za: Brzezińska, 2005) jest istotnym czynnikiem pozwalającym zachować sprawność umysłową, fizyczną, aktywność społeczną oraz ma znaczenie dla jakości życia.

Uczenie się w późnej dorosłości pomaga w:

- przekazywaniu umiejętności i wiedzy

- pozyskaniu lub utrzymaniu płatnej pracy

- byciu aktywnym obywatelem

- utrzymaniu zdrowia i jego poprawie

- „poruszaniu” się w wirtualnym, technologicznym świecie

- opiece nad rodzicami, wnukami, przyjaciółmi

- przezwyciężaniu kryzysów życiowych (rozwód, utrata bliskiej osoby, choroba)

- rozwoju w wolontariacie

- zarządzaniu finansami (McNair, 2012)

- lepszym radzeniu sobie z codziennymi wyzwaniami

- przejmowaniu odpowiedzialności za własne życie

- byciu bardziej niezależnym od innych

- lepszym wykorzystaniu własnego potencjału/zasobów

- realizowaniu zainteresowań i pasji

- rozwijaniu refleksyjności (większa samoświadomość i wgląd we własne problemy)

- poznaniu własnych praw i docenianiu swojej roli w społeczeństwie - obrona przed marginalizacją i respektowanie swych praw (Purdie, Boulton-Lewis, 2003 za: Brzezińska, 2005).

Tak liczne korzyści płynące z uczenia się w późnej dorosłości są dowodem na ważności problematyki osób starzejących się i starych w kontekście edukacji (uczenia się). Jednakże, osoby starzejące się i stare są wciąż najbardziej marginalizowaną grupą w polityce edukacyjnej w Europie. Wraz z uwypukleniem ekonomicznej konkurencyjności i moralną paniką odnośnie finansowej pomocy starzejącej się populacji (priorytet), późna dorosłość postrzegana jest głównie jako problem społeczny (Withnall, 2003). Wykluczenie osób starzejących się i starych niemal ze wszystkich dyskursów (oprócz ekonomicznego i medycznego) objawia się w postaci ageizmu. Przywołując stwierdzenie Andrzeja Radziewicza-Winnickiego (2005), iż „ludzie wykluczeni to te osoby, które przynależą do określonej wspólnoty, grupy czy społeczności, nie są w stanie (nie potrafią) w pełni korzystać z uprawnień, przywilejów i dobrodziejstw, jakie z tej przynależności wynikają" warto za- 
stanowić się nad zadaniami jakie stają przed szeroko rozumianą edukacją w kontekście marginalizowania starzenia się i starości. W literaturze anglojęzycznej edukacyjny dyskurs gerontologiczny jest wyraźnie widoczny od kilku dekad czego rezultatem jest powstanie krytycznej gerontologii edukacyjnej oraz wyłonionej z niej krytycznej geragogiki.

\section{Krytyczna gerontologia edukacyjna i krytyczna geragogika}

Jeden z gerontologów, zorientowany krytycznie Marvin Formosa (2012) zauważa, iż większość literatury gerontologicznej (także anglojęzycznej) zawiera różnego rodzaju braki, luki i ograniczenia. Twierdzi on, iż po pierwsze, dużo badań skoncentrowanych jest na zainteresowaniach osób pochodzących z klasy średniej, dobrze wykształconych, zdrowych oraz będących członkami dominującej etnicznie populacji. Po drugie, większość literatury koncentruje się na pozytywnych aspektach uczenia się osób starzejących się i starych, a rzadko widoczne są rozważania nad potencjalnie negatywnymi skutkami. Po trzecie, podejmowane incjatywy nie proponują różnych perspektyw uczenia się w kontekście posiadanych doświadczeń przez osoby starzejące się i stare, które doświadczają ucisku i dyskryminacji ze względu na wiek, klasę społeczną, gender lub pochodzenie (Fromosa, 2012).

Jak wcześniej wspomniałam, w polskiej literaturze gerontologicznej edukacyjny kontekst pojawia się incydentalnie, a wiedzę na temat krytycznej gerontologii edukacyjnej (critical educational gerontology - CEG) czy krytycznej geragogiki, znalazłam tylko w jednym opracowaniu (zob. Muszyński 2011).

Do prowadzenia dalszych rozważań istotne jest krótkie wyjaśnienie kilku pojęć, takich jak gerontologia edukacyjna, uczenie się osób w późnej dorosłości oraz krytyczna geragogika. Termin gerontologia edukacyjna dotyczy głównie integracji instytucji adresowanych do osób w późnej dorosłości, procesów edukacyjnych związanych z wiedzą na temat teorii starzenia się oraz potrzeb osób starzejących się i starych. Natomiast uczenie się w późnej dorosłości odnosi się do procesu, w którym osoby starzejące się i stare angażując doświadczenia (indywidualne i kolektywne), dokonują refleksji, uprawomacniają, nadają subiektywne znaczenia, poszukują sposobów rozumienia tych doświadczeń oraz otaczającej ich rzeczywistości (Formosa, 2012). Termin krytyczna geragogika (critical geragogy), wyłoniła się jako część krytycznej gerontologii edukacyjnej, a nazwa powstała w połączeniu krytycznej gerontologii z krytyczną edukacją (Formosa, 2011). Jest to jeden z para- 
dygmatów krytycznej gerontologii edukacyjnej, definiowany jako praktyka edukacyjna krytycznej gerontologii edukacyjnej, której celem jest emancypacja, upoważnianie/wzmocnienie (empowerment) oraz zaangażowanie starszych dorosłych (Glendenning and Battersby 1990 za: Formosa 2011). Krytyczna geragogika w swojej koncepcji spostrzega nauczanie i uczenie się jako zespołowe i negocjowalne przedsięwzięcie osób w późnej dorosłości. Osoby te posiadają możliwości zwiększenia energii, siły i kontroli we wszystkich aspektach aktywności edukacyjnej. Łączy teorię z praktyką/działaniem oraz dotyczy zarządzania strategiami nauczania i uczenia się osób w późnej dorosłości (Formosa, 2011).

Krytyczna gerontologia edukacyjna (critical educational gerontology $C E G)$ w teoretycznym ujęciu wskazuje, że starzejący się i starzy dorośli potrafią krytycznie myśleć, uczyć się, a także posiadają możliwość rozwoju, myślenia i refleksji nad posiadaną wiedzą oraz nad nowymi kontekstami uczenia się. Epistemologia krytyczna pojawiła się jako reakcja na dominujący paradygmat „spadku i straty” pokazujący starzenie się jako serię obniżenia wydajności (fizycznej, psychicznej, biologicznej), do której powinni przystosować się zarówno osoby starzejące się jak i społeczeństwo (Fromosa, 2011). Zmiana dominującego paradygmatu pojawiła się w latach 90-tych ubiegłego wieku pod wpływem pedagogiki krytycznej Paulo Freire (1996). Krytycznie zorientowani edukatorzy i badacze - Glendenning, Battersby zainspirowani filozofią edukacji P. Freire, stawiając za cel obudzenie w uczących się krytycznej świadomość i refleksji, stworzyli krytyczną edukację gerontologiczną (critical educational gerontology - CEG) (Formosa 2011, 2012). Apelowali do nauczycieli, edukatorów, aby swoje programy edukacyjne tworzyli uwzględniając krytyczną strukturę edukacyjną, która dostarczałaby osobom w późnej dorosłości możliwość krytycznej samoświadomości i refleksji nad życiem, doświadczeniami, a także możliwość do krytycznego działania (Formosa, 2012).

Glendenning i Battersby (Fromosa 2011, s. 319) wskazali cztery główne zasady konstytuujące krytyczną epistemologię edukacji w późnej dorosłości:

- prowadzenie badań wpływu połączeń kapitalizmu i starzenia się na rozumienie i praktykę edukacji w późnej dorosłości;

- krytyka, dotycząca negacji dominującej liberalnej tradycji, zakładającej że edukacja starzejących się i starych ludzi jest zasadniczo naturalną niekwestionowaną inicjatywą; 
- włączenie do edukacji takich koncepcji jak: emancypacja, upełnomacnianie (empowerment), transformacja, kontrola społeczna oraz to co Freire nazywał sumiennością/sprawiedliwością;

- rozwinięcie znaczących „pojęć praktyk” potrzebnych do ukonstytuowania się krytycznej geragogiki, która spowoduje że starzejący się i starzy ludzie będą w większym stopniu kontrolować swoją wiedzę i myśli.

Jednakże, jak każda teoria, także i krytyczna gerontologia edukacyjna nie jest wolna od krytyki (Percy 1990; Withnall 2000, 2002, 2006, 2010 za: Formosa 2011), która odkrywa luki oraz nowe, aktualne kierunki poszukiwań badawczych, a także wyraźniej uwypukla związek geragogiki z andragogiką czy też ideą uczenia się przez całe życie. Keith Percy (Formosa, 2012), cele CEG postrzega jako zbyt „niepewne”, ogólne oraz o szerokim zakresie, aby mogły zostać osiągnięte w grupach edukacyjnych do których uczęszcza zbyt mały procent osób w późnej dorosłości. Podkreśla natomiast że cele, założenia edukacji i uczenia się osób starzejących się i starych nie powinny się różnić od tych proponowanych osobom w innym (młodszym) wieku.

Krytykę CEG znajdujemy także u Alex Withnall (2003), która przyznaje, że Glendenning miał bezspornie duży wpływ na rozwój CEG w Anglii. Jego walka o nowy paradygmat eksplorujący edukację w trzecim wieku, dostarcza znaczącej wiedzy, która wymaga re-ewaluacji oraz polemiki (postawienia wielu pytań). Jednakże, Withnall (2003) przywołując stanowisko Ushera (1997 i inni), który w kontekście ogólnej edukacji dorosłych, stwierdza iż perspektywa krytyczna, która w założeniu prowadzi do odkrycia dysfunkcji i ograniczeń, jest aktualnie w kryzysie. Dążenie do emancypacji i uprawomocnienia może stać się nową formą ucisku samą w sobie. Dlatego też aspekt roli nauczycieli osób starzejących się i starych, zdaniem A. Withnall (2003) powinien być poddany szczegółowemu badaniu, gdyż problem jest bardziej złożony niż przyjmowano dotychczas.

\section{Znaczenie krytycznej gerontologii edukacyjnej dla funkcjonowania UTW}

Wzrastająca liczba Uniwersytetów Trzeciego Wieku (UTW) w Polsce z jednej strony świadczy o dużej potrzebie uczenia się osób w późnej dorosłości, z drugiej natomiast szczególnie w kontekście krytycznej gerontologii edukacyjnej, stawia nowe wyzwania badawcze. Dwa z nich wydają się znaczące: pierwsze dotyczy poziomu przygotowania metodycznego i gerontologiczne- 
go osób prowadzących zajęcia, kursy, lektoraty, warsztaty w UTW, drugie sposobu dokonywania oceny osiągnięć edukacyjnych słuchaczy UTW.

Analiza oferty edukacyjnej wrocławskich uniwersytetów trzeciego wieku (UTW w Uniwersytecie Wrocławskiem, UTW „Edukacja” Wyższej Szkoły Zarządzania, UTW Akademii Wychowania Fizycznego, UTW Uniwersytetu Ekonomicznego, Akademii Sztuk Trzeciego Wieku przy Towarzystwie Edukacji Otwartej, UTW Dolnośląskiej Szkoły Wyższej, UTW Uniwersytetu Przyrodniczego, UTW Wyższej Szkoły Humanistycznej) wskazuje na jej różnorodność, wielość i szeroki zakres. Z każdym rokiem przybywa seniorów zainteresowanych uczęszczaniem do UTW. Większa ilość słuchaczy UTW generuje większą ilość zajęć i liczbę prowadzących. Jak twierdzi Ewa Skibińska (2008), efektywność procesu kształcenia, nauczania czy raczej uczenia się seniorów w UTW zależy w dużej mierze od istotnego ogniwa jakim jest nauczyciel. Jego zadaniem jest poprowadzenie zajęć w taki sposób, aby uczący się osiągnęli jak największe sukcesy. Wyznaczenie jasnych i właściwych celów kształcenia nie jest prostym zadaniem dla nauczyciela, a formułowanie ich z perspektywy potrzeb osób starzejących się i starych może dostarczać dodatkowych utrudnień (Skibińska, 2008). Jednakże oprócz starannie dobranych celów istotne także, w procesie kształcenia czy uczenia się seniorów, są metody, formy i środki dydaktyczne. Dokonując ich wyboru do pracy z seniorami należy uwzględnić potrzeby, możliwości i ograniczenia jakie pojawiają się wraz z wiekiem (Skibińska, 2008). Osoby starzejące się i stare, jak twierdzi I. Stuart-Hamilton (2006), wykazują większe zróżnicowanie, niż osoby będące w okresie wczesnej dorosłości, co oznacza większe zindywidualizowanie pracy z uczącymi się seniorami.

Uczenie się w starości, jak już wcześniej wspomniałam, wpisuje się także w ideę uczenia się przez całe życie. Ewa Kurantowicz i Adrianna Nizińska (2012 s. 24-25 za: Shuller, Watson 2009) wyróżniają sześć przesłanek, na których opiera się uczenie się przez całe życie. Trzy z nich wydają się znaczące dla uczenia się w okresie późnej dorosłości. 1) „Ludzie są podmiotami uczącymi się - uczenie się jest ich naturalną zdolnością, ale jej realizacja wymaga różnorodności ofert edukacyjnych w różnych okresach życia”. 2) „Uczenie się zawsze wzmacnia moc panowania nad własnym życiem. Dzięki uczeniu się zdobywamy zdolność do jego kontrolowania. Rozumiemy zachodzące zmiany, potrafimy przystosować się do nich, a także wzbudzać i kształtować procesy zmieniające życie nasze lub innych”. 3) „Uczenie się przez całe życie wzmacnia i różnicuje społeczne kontakty jednostek, powoduje rozwój sieci społecznych w poprzek (czy na przekór) różnych podziałów społecznych, wiekowych, płciowych, rasowych itd. W konsekwencji przyczy- 


\section{2 | Małgorzata Malec Rawiński}

nia się do wzrostu kapitału społecznego, solidarności społecznej. Uczenie się samo w sobie jest aktem społecznym, a jego przebieg zależy od środowiska kulturowego i jego edukacyjnego potencjału". Takie rozumienie uczenia się i uczącego się, w odniesieniu do uczenia się seniorów w UTW wskazuje na ważność ciągłości uczenia się do późnych lat dorosłości. Poza tym osoby starzejące się i stare posiadają ogromne doświadczenie tak znaczące w teoriach uczenia się osób dorosłych, które powinno także stać się obszarem badań. W świetle powyższych wniosków, praca edukacyjna z osobami starzejącymi się i starymi wymaga odpowiedniego przygotowania andragogicznego, gerontologicznego oraz metodycznego.

\section{Propozycje badań i uwagi końcowe}

W związku z powyższymi rozważaniami oraz w kontekście założeń krytycznej gerontologii edukacyjnej, pojawiają się następujące pytania: jak w praktyce wygląda przygotowanie gerontologiczne i metodyczne osób pracujących (nauczycieli?) w UTW? W jakim stopniu wiedza i sposób (forma) jej przekazywania zwiększa kontrolę wiedzy i myśli osób starzejący się i starych? Jak przebiega proces uczenia się seniorów (teorie)? W jakim stopniu emancypacja, upełnomocnianie, transformacja, kontrola społeczna przejawiają się w procesie uczenia się osób w późnej dorosłości? Jak dokonywać oceny osiągnięć edukacyjnych słuchaczy UTW? Jakie znaczenie (wartość rozwojową, transformacyjną, poznawczą) ma uczenie się seniorów w UTW?

Powyższe pytania mogą stanowić prowokację lub inspirują do podjęcia badań naukowych, które uprawomocnią uczenie się osób starzejących się i starych oraz ugruntują ich potencjał edukacyjny, a także sprawią, że uniwersytety trzeciego wieku nie będą tylko miejscem dobrych praktyk edukacji pozaformalnej i nieformalnej, ale staną się ośrodkami badawczymi. Proponowane badania dostarczyłyby także naukowych dowodów potwierdzających możliwości, umiejętności uczenia się oraz ogromnego zaangażowania w przyswajaniu wiedzy osób w późnej dorosłości. Poza tym umożliwiłyby osobom starzejącym się i starym krytyczną refleksję nad życiem i wzmocniłyby ich samoświadomość i poczucie sprawstwa. Jak twierdzi Alexandra Withnall (2003, s. 295) „uczenie się w późnej dorosłości może zawierać elementy refleksji i syntezy życia, odbywać się w nieustruktualizowany i spontaniczny sposób, ale który może prowadzić do głębokiego samo-zrozumienia i wglądu w siebie". 
Jak pokazują przytoczone powyżej badania, uczenie się w późnej dorosłości poprawia jakość życia seniorów, wzmacnia w nich poczucia sprawstwa i ważności oraz rozwija. Zatem istotne jest, w moim przekonaniu, jak postuluje idea CEG, zwiększenie energii, siły i kontroli seniorów we wszystkich aspektach aktywności edukacyjnej, aby dążenie do emancypacji i uprawomocnienia nie stało się nową formą ucisku samą w sobie. Jest to możliwe kiedy badacze edukacji osób dorosłych zaczną traktować osoby starzejące się i stare jako potencjał edukacyjny.

\section{Bibliografia}

Błachnio A. (2012), Starość non profit. Wolontariat na Uniwersytetach Trzeciego Wieku w Polsce i na świecie, Wyd. Uniwersytetu Kazimierza Wielkiego, Bydgoszcz.

Brzezińska A. (2005), Psychologiczne portrety człowieka. Praktyczna psychologia rozwojowa, GWP, Gdańsk.

Czerniawska O. (2007), Szkice z andragogiki i gerontologii, Wyd. Wyższej Szkoły Humanistyczno-Ekonomicznej, Łódź.

Formosa M. (2011), Critical educational gerontology: a third statement of first principles, "International Journal of Education and Ageing", 2 (1), p.300-317.

Formosa M. (2012), Critical Geragogy: Situating Theory, "Journal of Contemporary Educational Studies", 5, p.36-54.

Freire P. (1996), Pedagogy of the oppressed, Penguin Books, London.

Halicki J. (2010), Obrazy starości. Rysowane przeżyciami seniorów, Białystok, Wyd. Uniwersytetu w Białymstoku.

Hill R.D. (2010), Pozytywne starzenie się, Laurum,Warszawa.

Kurantowicz E., Nizińska A. (2012), Trajektorie uczenia się w instytucjach kształcenia ustawicznego, Wyd. Naukowe DSW, Wrocław.

Leszczyńska-Rejchert A. (2005), Człowiek starszy i jego wspomaganie: w stronę pedagogiki starości, Wydaw. Uniwersytetu Warmińsko-Mazurskiego, Olsztyn.

Muszyński M. (2011), Do czego potrzebne są nam teorie starzenia się? [w:] S. Słowińska (red.), „Dyskursy Młodych Andragogów”, Zielona Góra.

Purdie N., Boulton-Lewis G., (2003), Learning needs of older adults, Educational Gerontology "An International Journal", 29(2), p.129-149.

Skibińska E. (2006), Mikroświaty kobiet. Relacje autobiograficzne, Wyd. Uniwersytetu Warszawskiego, Warszawa.

Skibińska E. (2008), Proces kształcenia seniorów, [w:] A. Fabiś (red.) Aktywność społeczna, kulturalna i oświatowa seniorów, Biblioteka Gerontologii Społecznej, Bielsko Biała.

Stuart- Hamilton I. (2006), Psychologia starzenia się. Wprowadzenie, Wyd. Zysk i S-ka, Poznań. 


\section{4 | Małgorzata Malec Rawiński}

Szarota Z. (2010), Starzenie się i starość w wymiarze instytucjonalnego wsparcia, Wyd. Uniwersytetu Pedagogicznego, Kraków.

Szatur-Jaworska B., Błędowski P., Dzięgielewska M. (2006), Podstawy gerontologii społecznej, Oficyna Wydawnicza Aspra-Jr, Warszawa.

Wawrzyniak J. (2009), Oblicza starości: biografia jako źródło czynników adaptacyjnych, Wydawnictwo Wyższej Szkoły Humanistyczno-Ekonomicznej, Łódź.

Withnall A. (2003), Reflection on lifelong learning and the Third Age [in:] J. Field \& M. Leicester (ed.) Lifelong Learning: Learning Across the Lifespan, London and New York.

Zboina B. (2008), Jakość życia osób starszych, Stowarzyszenie „Nauka Edukacja Rozwój", Ostrowiec Św.

Zych A. (1999), Człowiek wobec starości, „Śląsk”, Katowice.

\section{Netografia}

Gołdys A., Krzyżanowska Ł., Stec M., Ostrowski Ł., 2012, Zoom na UTW. Raport z badania, http://zoomnautw.pl/wyniki-badania/

WHO http://www.who.int/ageing/about/facts/en/

Wodecka D., 2008, Kiedy jeżdżę na rolkach, smarkacze krzyczq̨: Dziadek do piachu! http://wyborcza.pl/51,95755,5953936.html?i=1 